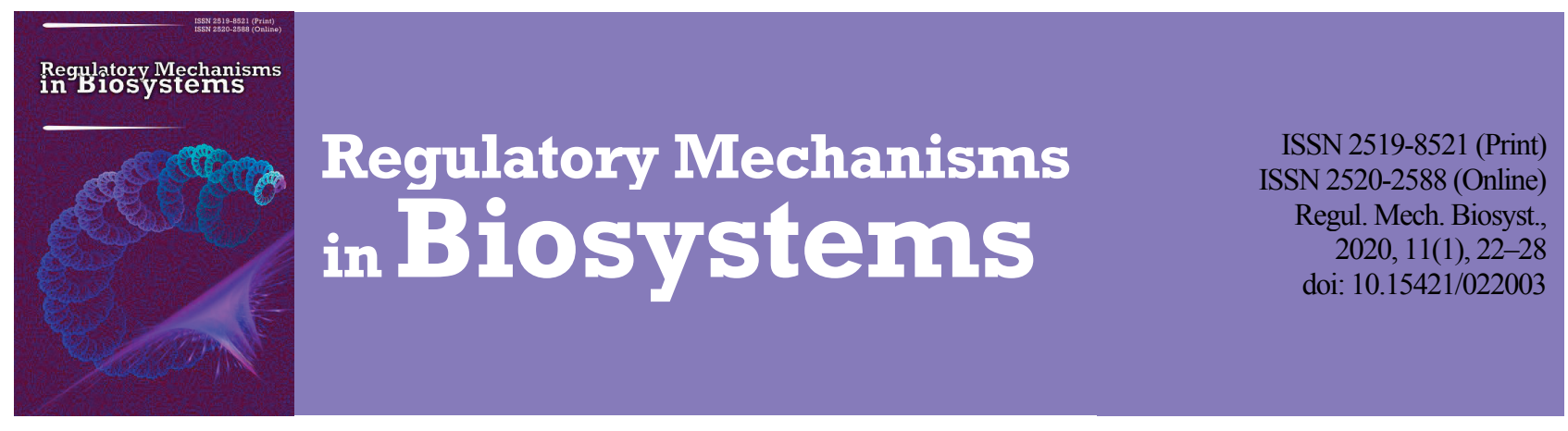

\title{
Morphogenesis and vitality of seedlings of Ginkgo biloba in outdoor conditions
}

\author{
I. M. Kovalenko*, G. O. Klymenko*, T. I. Melnik*, R. A. Yaroshchuk*, S. V. Zherdetska*, Y. Su*, O. A. Lykholat** \\ *Sumy National Agrarian University, Sumy, Ukraine \\ **University of Customs and Finance, Dnipro, Ukraine
}

Article info

Received 17.01.2020

Received in revised form 12.02 .2020

Accepted 13.02.2020

Sumy National Agrarian University, Kondratyeva st., 160/5, Sumy, 40021, Ukraine. Tel.: +38-095-407-72-48 E-mail: annaklimenko2014 (a)gmail.com

University of Customs and Finance, Volodymyr Vernadsky st., 2/4 Dnipro, 49000, Ukraine.
Kovalenko, I. M., Klymenko, G. O., Melnik, T. I., Yaroshchuk, R. A., Zherdetska, S. V., Su, Y., \& Lykholat, O. A. (2020). Morphogenesis and vitality of seedlings of Ginkgo biloba in outdoor conditions. Regulatory Mechanisms in Biosystems, 11(1), 22-28. doi:10.15421/022003

Ginkgo biloba L. is a relic tree that is preserved in natural conditions only in China. In the North-East Ukraine ginkgo is only in the process of introduction, but in certain places ginkgo trees are grown for decorative purposes which show high vitality. Therefore a relevant and promising task is the creation of industrial plantations of ginkgo for collection of its leaves. The objective of the study was morphological peculiarities of ginkgo plants and their vital condition depending on the calendar age of the seedlings at the stage when they were transplanted into the soil. For growing ginkgo, in our studies, a combined two-stage system was approbated, according to which seedlings were grown in greenhouses during 2-3 years, and then moved into soil outdoors. In our study, as planting material we used seedlings of ginkgo from a plant nursery (greenhouse) of Sumy National Agrarian University planted in 2014 and 2015. Seedlings were planted in the soil in early spring. Seedlings for growth completion were planted in rows with inter-row distance of $0.8 \mathrm{~m}$ and distance between the plants measuring $2.5-3.0 \mathrm{~m}$. We studied the condition of the seedlings in two variants: variant 1 - three-year old seedlings obtained in the greenhouse were transplanted in spring 2018; variant 2 - two-year old seedlings obtained in greenhouse were transplanted in spring 2017. Comparative morphometric analysis and evaluation of vitality of these plants was performed in August 2019. Both groups of seedlings were five years old at the time of survey. For evaluation of morphometric structure of the ginkgo seedlings and their vital condition we used randomized selections of specimens in amount of up to 30 from plantations of variants 1 and 2. Analysis of the plants was conducted during the end of the vegetative period of 2019, when active growth of the plants stopped. Four main parameters of the plants were recorded: height, value of annual increment, diameter of the stem near the root neck and the number of leaves. Vital condition of the seedlings was evaluated on the basis of algorithm of vital analysis. Vitality of each seedling was evaluated by the coefficient of $Q$ vitality, value of which was in interval from 0 to 1.0. Depending on the value of $Q$ the seedlings were divided into five classes of vitality: $0-0.2-\mathrm{cc}$ (specimens of the lowest vitality), $0.2-0.4-\mathrm{c}$ (low vitality), 0.4-0.6 - b (average vitality), 0.6-0.8 - a (high vitality), 0.8-1.0 - aa (specimens with highest vitality). Comparative analysis of morphological peculiarities of the ginkgo seedlings revealed that two-year plants transplanted outdoors from the greenhouse had higher annual increment of the main stem, diameter of stem and number of leaves. Vital condition of such seedlings was the highest and was evaluated using $Q$ index, which ranges between vitality of classes $b$ to aa. This allows recommending a two-stage scheme of growing seedlings of ginkgo in North-East Ukraine. The optimum age for transplanting seedlings from greenhouses to open soil is two years.

Keywords: vitality analysis; relic species; morphometric analysis; medical raw material.

\section{Introduction}

The negative effect of abiotic and biotic environmental factors, against the background of climate changes, in the conditions of Ukraine is inevitably reflected in the condition of the soil (Savosko et al., 2018), vegetation (Lykholat et al., 2018a, 2018b; Nazarenko et al., 2018), animals (Boyko \& Brygadyrenko, 2016; Faly et al., 2017; Didur et al., 2019; Pokhylenko et al., 2019) and significantly affects the health of the population (Kotsariev et al., 2001; Pertseva et al., 2008, 2012; Lykholat et al., 2016). Preservation of the existing biological diversity and enlargement of its range in Ukraine is possible using relic species, including Ginkgo biloba L. This plant is a relic tree which has been preserved in natural conditions only in China. From China ginkgo was brought to Holland in 1730. Currently, due to the value of ginkgo as a source of medical substance it is being grown in many countries of the world. Further contributory factors to this are the plant's decorative value and its undemanding requirements regarding growth conditions.

Due to the medical and decorative values of ginkgo, its biology, ecology, biochemistry and technologies of growth are described in se- veral monographs and numerous articles (Tereshchuk, 2009; Crane, 2013; Fisher, 2016; Tereshchuk, 2009).

Ginkgo plants are trees of $30-40 \mathrm{~m}$ height with trunk diameter measuring up to $3 \mathrm{~m}$ and crown diameter of $25 \mathrm{~m}$. The lifespan of these trees can reach up to 2,000 years.

Ginkgo is a dioecious gymnosperm plant. Generative reproduction of ginkgo begins only at 20-30 years. On male trees, microstrobili small cones with microspores - are formed in spring, and on female plants macrostrobili emerge, containing seed embryos. Inflorescence of ginkgo is inconspicuous, the plant is wind-pollinated. After pollination, on female trees, seeds with three-layer seed cover form. The development of embryo occurs in ginkgo in non-ripened seeds which have already fallen from the tree, at low positive temperatures. The process of embryo development in ginkgo seeds lasts approximately 3-4 months after they have fallen.

Leaves of ginkgo have a specific structure. They are two-lobed, 5$8 \mathrm{~cm}$ in width. The leading bundles in the leaf blades ramify dichotomously (Shchyrova et al., 2002). Ginkgo is characterized by heterophylly. In spring, on the plants' shortened stems, the first "early leaves" 
emerge from wintering buds. In early summer and throughout the season, the "late leaves" form on the gingko stems. Particularly those twolobed leaves are more characteristic for this plant (Critchfield, 1970). Leaves on shortened shoots are thinner, the network of leading bundles in them is more dense and has fewer stomata (Leigh et al., 2011).

Ginkgo is a deciduous plant and therefore in autumn thus leaves fall off. In China, the leaves of ginkgo have been used for medical purpose since ancient times. In European countries and the USA active research and medical use of the plant began in the middle of the XX century. Up to the present, research has revealed that the extracts of ginkgo leaves are effective against a broad group of diseases - memory dysfunctions, chronic diseases of vessels of the brain, Alzheimer's disease, decline in hearing ability, impaired blood circulation, including capillary, atherosclerosis, hemorrhoid and a number of other conditions (Yoshikawa et al., 1999; Diamond et al., 2000; Mahadevan \& Park, 2008; Kuznetsova \& Shulzhenko, 2015).

Moreover, overview research by Po-Chuen Chan with the coauthors (Po-Chuen et al., 2007) referencing to 162 literature sources states that extracts from leaves of ginkgo have a general health-improving effect on the human organism, increase stability of the nervous system against stress impacts, and slow the ageing process.

Extract from ginkgo leaves has a complex chemical composition. It includes over 40 biologically active ingredients. Standardized extract from leaves of Ginkgo biloba L. used in modern medicine contains three main groups of substances that determine specific pharmacologic activity. They are as follows:

a) terpene trilactones (bilobalide and ginkgolides), their content equals $5.4-12.0 \%$;

b) various bioflavonoids, which account for $24-27 \%$;

c) proanthocyanidins, organic acids, ginkgolic acids, nitrogen bases (thymine), microelements.

Most valuable pharmacologically are terpene trilactones and bioflavonoids (Bikram et al., 2008; Singh et al., 2008).

Technologies of obtaining medical forms (tablets, capsules, etc.) from ginkgo leaves vary in different pharmaceutical companies. The quality of the output material also varies. In Germany a standard has been developed, according to which the extract of ginkgo leaves should contain 22 $27 \%$ of flavonoid glycosides, 5-7\% of terpene lactones and no less than 5 parts per million of ginkgolic acids (Jacobs \& Browner, 2000).

During preparation of leaves, one must take into account that the highest amount of such substances as rutin, kaempferol and bilobetin is present in young leaves until the middle of summer, whereas the amount of bioflavonoids is the highest in the autumn leaves which begin to turn yellow and fall off (Lobstein et al., 1991). Maximum amount of polyphenolic compounds in the leaves was recorded during the ripening and falling off of the fruits (Yudina et al., 2010). Therefore, two-time preparation of ginkgo leaves as medical raw material can be recommended: the first - in the middle of the summer with collection of up to $30 \%$ of leaves from the trees, the second - at the very beginning of November. Traditional periods of collecting leaves for obtaining medical substances have established: July in the USA, August in China, September-October in France (Schmid \& Baltz, 2003), in Lithuania the best period for preparation of leaves is believed to be July-August (Rimkiene et al., 2017). Leaves of ginkgo are collected manually or using special devices. The output of useful production (leaves) depends on the age of the tree and the region. In India, in pre-mountain areas of the Himalayas in some years 30 t/ha of leaves are collected (Gopichand \& Meena, 2015).

In the conditions of the steppe Ukraine ginkgo grows well and survives winters under the open sky (Burda \& Koniakin, 2019). The plant is low-demanding for soil fertility. The plant is resistant to pests and diseases. However, in the conditions of Poltava oblast cases have been recorded of damage to leaves by diseases caused by Alternaria, and damage to seeds by Monilinia (Samorodov \& Pospelova, 2016).

In North-East Ukraine the growing of ginkgo is only in the process of development, but in some places ginkgo trees grown for decorative purposes show high vitality. Therefore, a relevant and promising task is the creation of industrial plantations of ginkgo, necessary for preparation of leaves. Peculiarities of growing ginkgo in the conditions of North-
East Ukraine have not been determined. The study was aimed at survey of morphological peculiarities of ginkgo plants and their vital condition depending on the region of seed origin, calendar age of the seedlings at the time they were transplanted to the open ground.

\section{Materials and methods}

For growing ginkgo plants in Sumy, a special comparative analysis was performed for seeds obtained in different climatic conditions, particularly the forest-steppe region (Kamianets-Podilsky) and steppe region (Odessa): morphometric characteristics of ginkgo seeds were studied: length of seed, rim width, cross-section width of seed, mass (expressed as air dry weight). The amount of the selection was 100 for seeds obtained in Kamianets-Podilsky, and 98 for seeds from Odessa.

In our studies, for planting ginkgo a combined two-stage scheme was approbated, according to which the seedlings were grown in greenhouses for 2-3 years, and then continued growing in open soil.

Earlier, similar technology of growing ginkgo was developed by A. O. Ostudimov for the conditions of Lviv Oblast (Ostudimov \& Guz, 2010; Ostudimov, 2011). It includes growing 1-3 summer seedlings of ginkgo from seeds in greenhouse conditions, followed by their growing up to the required sizes outdoors.

In our study, as planting material we used ginkgo seedlings from the plant nursery (greenhouse) of Sumy National Agrarian University planted in 2014-2015. Their characteristic is provided in the studies by Yaroshchuk (2016) and Kovalenko et al. (2018).

Transplantation of seedlings into the soil took place in early spring. The seedlings for growth completion were planted in rows with $0.8 \mathrm{~m}$ distance between the rows and 2.5-3.0 m between the rows.

We studied the condition of seedlings in two variants: variant $1-$ three-year seedlings grown in the greenhouse were transplanted in spring of 2018; variant 2 - two-year seedlings started in the greenhouse were transplanted in spring of 2017.

The comparative morphometric analysis and evaluation of vitality of these plants were performed in August of 2019. Both groups of seedlings were five years old at the period of examining their condition.

The typical seedlings at the end of vegetative period of 2019 looked as shown in Figure 1. For evaluation of the morphological structure of ginkgo seedlings and their vital conditions, randomized selections of up to 30 specimens from variants 1 and 2 were used. Analysis of plants was undertaken in the end of the vegetative period of 2019, when active growth of plants had stopped. The plants were analyzed for four main parameters: height, size of the annual increment, diameter of stem near the root neck and amount of leaves.

The vital condition of the seedlings was evaluated on the basis of algorithm of the vitality analysis (Zlobin, 2018). The method has been successfully used both for determining the vitality of populations of herbaceous plants (Zlobin \& Klimenko, 2010; Tikhonova, 2011; Kyrylchuk, 2014) and tree plantations (Skliar, 2013; Skliar \& Zlobin, 2013). The vitality of each seedling was evaluated by vitality coefficient $Q$, the value of which ranged 0.0-1.0. Depending on the $\mathrm{Q}$ value, the seedlings were divided into five vitality classes: $0.0-0.2-\mathrm{cc}$ (specimens of the lowest vitality), $0.2-0.4-\mathrm{c}$ (low vitality), $0.4-0.6-\mathrm{b}$ (average vitality), $0.6-0.8-\mathrm{a}$ (high vitality), $0.8-1.0-$ aa (specimens with highest vitality).

Vitality of population as group of specimens was determined according to the formula:

$$
\mathrm{Q}=(\mathrm{aa} / \mathrm{n}+\mathrm{a} / \mathrm{n}+\mathrm{b} / \mathrm{n})
$$

where $a a, a$ and $b$ - quantity of the specimens of the respective class of vitality selection, $\mathrm{n}-$ amount of the selection. This indicator allows evaluation of the entire group of seedlings.

Kamianets-Podilsky $\left(48^{\circ} 40^{\prime} 50^{\prime \prime} \mathrm{N}, 26^{\circ} 34^{\prime} 50^{\prime \prime} \mathrm{E}\right)$ is located in the West Ukrainian province of forest-steppe physical-geographical zone. The climate of Khmelnytsky region is moderately-continental with a short, mild winter, relatively dry spring (low amount of precipitation in April), rainy summer and relatively dry autumn. According to the distribution of thermal resources of climate, the territory of Khemelnytske Transnistria, to which Kamianets-Podilsky belongs, is characterized by an average annual temperature of $+7.5-7.9^{\circ} \mathrm{C}$, the norm of annual precipitations of $600 \mathrm{~mm}$, the sum of temperatures over $10^{\circ} \mathrm{C}$ in the 
interval of 2,650-2,750 ${ }^{\circ} \mathrm{C}$. By the pattern of geographical zoning, the city of Odessa $\left(47^{\circ} \mathrm{N}, 30^{\circ} \mathrm{E}\right)$ is located in the Prymorie plain area of the Prychornomorska-Pryazovska southern steppe (dry steppe) province of the steppe zone.

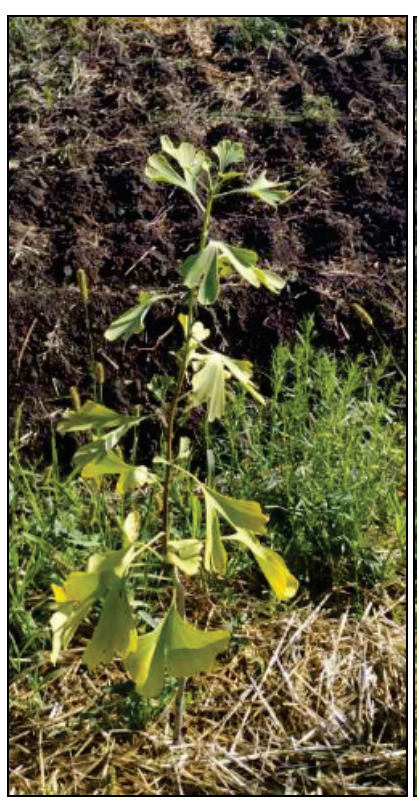

a

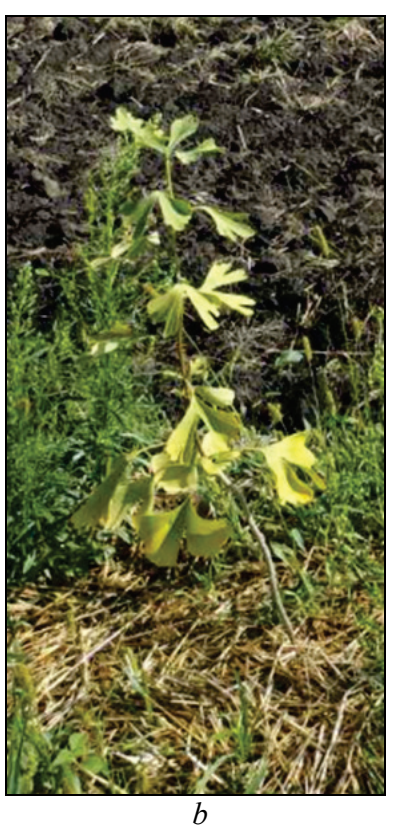

$b$
Fig. 1. Typical seedling of ginkgo from two variants: $a$-Variant 1, plantation of 3-year plants; $b$ - Variant 2, plantation of 2-year plants
The climate in Odessa oblast is moderately continental with insufficient moisture, a short, mild winter and long hot summer. The distribution of thermal resources in Odessa is as follows: average annual temperature is $+10.7^{\circ} \mathrm{C}$, the norm of annual precipitations $-451 \mathrm{~mm}$, total of the temperatures over $10^{\circ} \mathrm{C}$ in the interval of $3,200-3,400{ }^{\circ} \mathrm{C}$. Sumy $\left(50^{\circ} 54^{\prime} 24^{\prime \prime} \mathrm{N}, 34^{\circ} 47^{\prime} 57^{\prime \prime} \mathrm{E}\right)$ is located in South-East part of Ukraine in the forest-steppe physical-geographical zone. The climate of this region is continental: with a mild winter and warm summer. Annual relative air moisture on average equals 78\%, is the lowest in May (64\%) and highest in December (89\%) (Gorun, 2013; Trygub, 2016).

The survey results were statistically analyzed using the generally accepted modern methods of mathematical statistics with use of dispersion and vitality analysis. We used the computer software pack Statistica 8.0. Using methods of multiple regression, mathematical models were developed, connecting mass of Ginkgo biloba L. seed with its length, rim width of seed and cross-section width of seed.

\section{Results}

Comparative analysis of the main morphometric characteristics of seeds of ginkgo in different climatic conditions of growing revealed the following: among such morphometric characteristics of ginkgo seeds as length of seed, rim width of seed, cross-section width of seed, mass of seed depending on the climatic conditions of growing, a reliable difference between the average values was found for rim width of seed and mass of seed (Table 1). The obtained values were lower for seeds obtained in the conditions of Odessa oblast with insufficient level of moisture and long hot summer.

On the basis of obtained morphometric data and their further statistical processing, by methods of multiple regression, the mathematical models were obtained, connecting the mass of seed with its length, rim width of seed and cross-section width of seed.

Table 1

The main characteristics of ginkgo seeds in different climatic conditions of growing

\begin{tabular}{|c|c|c|c|c|c|c|c|}
\hline Parameter & Selection & $\begin{array}{c}\text { Mean } \\
\text { arithmetic error }\end{array}$ & Median & $\begin{array}{l}\text { Standard } \\
\text { deviation }\end{array}$ & $\begin{array}{c}\text { Variation } \\
\text { coefficient, } \%\end{array}$ & $\begin{array}{l}\text { Asym- } \\
\text { metry }\end{array}$ & Excess \\
\hline Length of seed, mm (conditions of Kamianets-Podilsky) & 100 & $20.62 \pm 0.28$ & 21.71 & 2.80 & 0.14 & -1.61 & 3.11 \\
\hline Length of seed, $\mathrm{mm}$ (conditions of Odessa) & 98 & $20.67 \pm 0.07$ & 20.73 & 0.74 & 3.60 & -0.47 & 0.12 \\
\hline Rim width of seed, $\mathrm{mm}$ (conditions of Kamianets-Podilsky) & 100 & $15.61 \pm 0.26^{* *}$ & 16.57 & 2.60 & 0.17 & -0.42 & -0.39 \\
\hline Rim width of seed, mm (conditions of Odessa) & 98 & $14.83 \pm 0.09$ & 14.90 & 0.92 & 0.06 & -0.80 & 1.54 \\
\hline cross-section width of seed, mm (conditions of Kamianets-Podilsky) & 100 & $12.37 \pm 0.24$ & 13.48 & 2.36 & 0.19 & -0.92 & -0.63 \\
\hline cross-section width of seed, mm (conditions of Odessa) & 98 & $12.10 \pm 0.05$ & 12.16 & 0.54 & 0.04 & -0.58 & 0.31 \\
\hline Mass of seed, $g$ (conditions of Kamianets-Podilsky) & 100 & $2.40 \pm 0.04^{* * *}$ & 2.46 & 0.36 & 0.15 & 0.12 & 2.91 \\
\hline Mass of seed, $\mathrm{g}$ (conditions of Odessa) & 98 & $1.68 \pm 0.02$ & 1.70 & 0.22 & 0.13 & 0.61 & 4.95 \\
\hline
\end{tabular}

Note: statistically reliable difference with significance level (according to Student's criterion): $* *-0.01-0.001 ; * * *-\leq 0.001$.

For the conditions of forest-steppe zone the equation of regression looked as follows:

$\mathrm{M}$ seed $=0.1035 * \mathrm{~L}$ seed $+0.0972 * \mathrm{~W}$ seed rim Kam $-0.1031 * \mathrm{~W}$ seed cross-section $\left(\mathrm{R}^{2}=97.5 \%\right.$; corrected $\left.\mathrm{R}^{2}=97.4 \%\right)$, where M seed - mass of seed ( $\mathrm{g}$ ), L seed - length of seed (mm), W seed rim - rim width of seed, $\mathrm{W}$ seed cross-section - cross-section width of seed (mm).

A peculiarity of the abovementioned equation of regression is that the free member of the equation is excluded from the model. Such an approach allowed us to obtain an equation with the best statistical characteristics, and also to quantitatively evaluate the effect of each factor (independent variable) on the extent of the manifestation of the parameter of optimization (dependent variable, Table 2).

\section{Table 2}

Statistical evaluation of independent variables in the mathematical model for seeds of ginkgo grown in the territory of forest-steppe zone (Kamianets-Podilsky)

\begin{tabular}{lcccr}
\hline \multicolumn{1}{c}{ Parameter } & Estimate & Standard Error T Statistics & P-Value \\
\hline L seed & 0.1035 & 0.0214 & 4.84 & $<0.0001$ \\
W seed rim & 0.0972 & 0.0311 & 3.12 & 0.0024 \\
W seed cross-section & -0.1031 & 0.0393 & -2.62 & 0.0102 \\
\hline
\end{tabular}

During the following statistical evaluation of the proposed mathematical model, we found that it has a high level of applicability (indicated by high coefficient of determination in the regression equation, equaling $97.5 \%$ ) and reflects the orientation of changes of mass of the formed seed depending on the contribution of length and rim width of seed and cross-section width of seed. Furthermore, the developed mathematical model of predicting the mass of seed of G. biloba is adequate due to high level of significance of P-value (Table 3).

Table 3

Dispersion analysis of mathematical model for seeds of G. biloba which grow in the conditions of the forest-steppe (Kamianets-Podilsky)

\begin{tabular}{lcrccc}
\hline \multicolumn{1}{c}{ Source } & Sum of Squares & Df & Mean Square & F-ratio & P-value \\
\hline Model & 573.99 & 3 & 191.33 & 1282.99 & $<0.0001$ \\
Residual & 14.46 & 97 & 0.12 & - & - \\
Total & 588.46 & 100 & - & - & - \\
\hline
\end{tabular}

For the conditions of the steppe zone, the regression equation is as follows:

$\mathrm{M}$ seed $=-0.0470 * \mathrm{~L}$ seed $+0.0668 * \mathrm{~W}$ seed $\mathrm{rim}+0.1372 * \mathrm{~W}$ seed cross-section $\left(\mathrm{R}^{2}=99.0 \%\right.$; corrected $\left.\mathrm{R}^{2}=98.9 \%\right)$, 
where M seed - mass of seed ( $\mathrm{g}$ ), L seed - length of seed (mm), W seed rim - width of seed along the margin, $\mathrm{W}$ seed cross-section - crosssection width of seed ( $\mathrm{mm})$.

In the abovementioned regression equation, similarly to the previous case, the free member is excluded from the model. This allowed us to obtain the equation with the best statistical characteristics and also quantitatively evaluate the effect of each factor (independent variable) on the extent of manifestation of the dependent variable (Table 4).

Table 4

Dispersion analysis of mathematical model for seed of which grows in the steppe in conditions of insufficient moisture (Odessa)

\begin{tabular}{lrcrc}
\hline \multicolumn{1}{c}{ Parameter } & Estimate & Standard Error & T statistic & P-value \\
\hline L seed & -0.0470 & 0.0222 & -2.12 & 0.0370 \\
W see rim & 0.0668 & 0.0251 & 2.66 & 0.0091 \\
W seed cross-section & 0.1372 & 0.0340 & 4.03 & 0.0001 \\
\hline
\end{tabular}

Conducting the statistical evaluation of the proposed mathematical model we found that it has a high level of applicability (indicated by the high coefficient of determination of regression in the equation, equaling $99.0 \%$ ) and reflects changes in the mass of the formed seeds depending on the contribution of length and rim width and cross-section width of seed. Furthermore, the developed mathematical model can be used for predicting mass of G. biloba seed and is adequate due to the high level of significance of P-value (Table 5).

Table 5

Dispersion analysis of mathematical model for seeds of G. biloba which grow in the conditions of steppe (Odessa)

\begin{tabular}{lcrccc}
\hline \multicolumn{1}{c}{ Source } & Sum of Squares & Df & Mean Square & F-Ratio & P-Value \\
\hline Model & 278.01 & 3 & 92.669 & 3147.48 & $<0.0001$ \\
Residual & 2.79 & 95 & 0.029 & - & - \\
Total & 280.80 & 98 & - & - & - \\
\hline
\end{tabular}

The obtained mathematical models of evaluation of predicting mass of seeds from $G$. biloba which grew in different climatic zones conditioned the expedience of using seeds from forest-steppe conditions (Kamianets-Podilsky) in further studies.

Comparative morphometric analysis of two variants of planting ginkgo plants showed (Table 6) that planting two-year old seedlings (variant 2) led to better growth and development of the plants. They exceeded the plants which were transplanted at the age of three years (variant 1) in the annual increment of the main stem, diameter of the
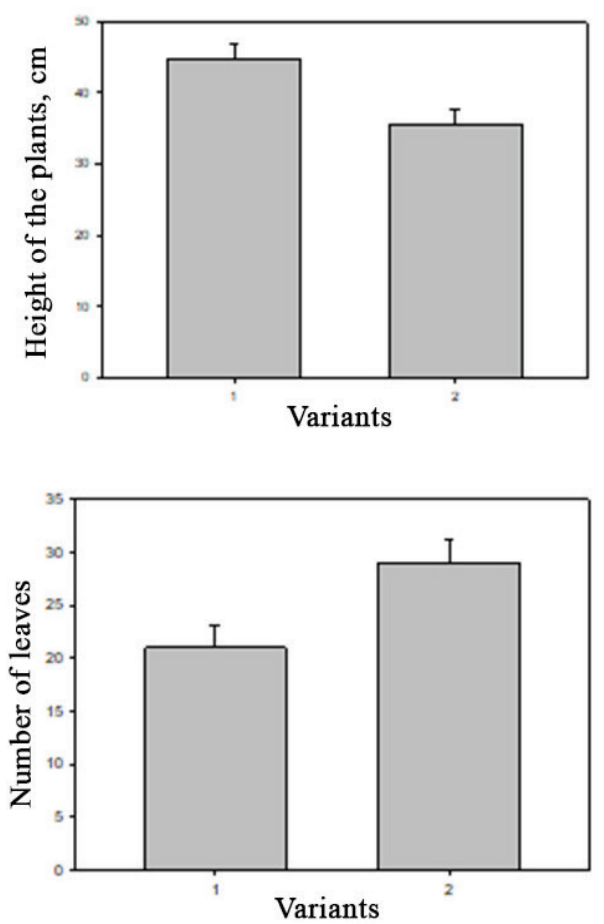

stem and number of leaves, being inferior to them only in height (Fig. 2). Plants that developed from the two-year seedlings exceeded the threeyear old plants by annual increment only by $0.4 \mathrm{~cm}$, by $0.15 \mathrm{~cm}$ by the stem diameter, and in number of leaves by 8 . These differences were statistically reliable only at the level of $\mathrm{P}=0.00-0.03$.

Table 6

The main morphostructural parameters of seedlings of G. biloba

\begin{tabular}{lcccc}
\hline \multirow{2}{*}{ Parameters } & \multicolumn{2}{c}{ Mean arithmetic } & \multicolumn{3}{c}{ Minimum Maximum } & Variation \\
& value and its error & value & value & coefficient \\
\hline \multicolumn{5}{c}{ Variant 1 } \\
Height of plants & $44.7 \pm 2.32$ & 20.5 & 68.0 & 28.5 \\
Annual increment & $13.7 \pm 1.46$ & 1.0 & 28.4 & 58.2 \\
Number of leaves & $21.0 \pm 2.13$ & 8.0 & 58.0 & 55.4 \\
Stem diameter & $1.43 \pm 0.01$ & 1.25 & 1.52 & 5.1 \\
\hline \multicolumn{5}{c}{ Variant 2 } \\
Height of plants & $35.5 \pm 2.29$ & 20.4 & 73.2 & 35.3 \\
Annual increment & $14.1 \pm 1.14$ & 3.1 & 28.2 & 44.2 \\
Number of leaves & $29.0 \pm 2.91$ & 7.0 & 68.0 & 54.9 \\
Diameter of stem & $1.58 \pm 0.004$ & 1.60 & 1.64 & 1.63 \\
\hline
\end{tabular}

Difference by the size of annual increment of the main stem between the plants of the first and the second variants was statistically unreliable (Table 7). Obviously this is related to the fact that annual increments reflect the conditions of the current vegetative period the best. Earlier the specialists determined that over the first three years after being planted the seedlings develop a root system, having minimum increments of the stems during that period (Crane, 2013). Morphostructural uniformity of the total of seedlings of the variants 1 and 2 was approximately similarly low. Variation coefficient (Table 6) for the size of annual increment of shoots and the number of leaves was within the range of $44-58 \%$, height of plants $-28-35 \%$. The lowest variation parameter was the stem diameter ranging $1.6-5.0 \%$.

Table 7

Dispersion analysis of morphometric features of seedlings of G. biloba

\begin{tabular}{lccc}
\hline \multicolumn{1}{c}{ Parameters } & Mean square & Fisher criterion & Reliability level, P \\
\hline Height of plants & 1272 & 7.99 & $0.006^{*}$ \\
Annual increment & 1.7 & 0.03 & 0.856 \\
Number of leaves & 960 & 4.92 & $0.030^{*}$ \\
Diameter of stem & 0.301 & 99.06 & $0.000^{*}$ \\
\hline
\end{tabular}

Note: Sign * marks parameters by which the seedlings of variants 1 and 2 statistically reliably differed from one another.
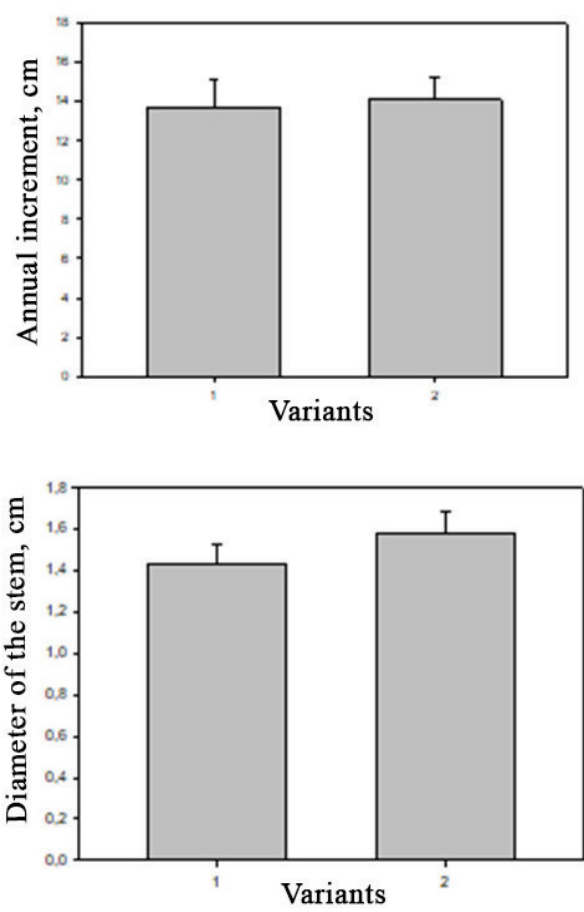

Fig. 2. Main morphometric features of $G$. biloba seedlings according to variants of planting: numbers of the variants are indicated by figures 
For the integral evaluation of the vital condition of the seedlings we used vitality analysis. The evaluation of vitality of some seedlings by a combination of four recorded parameters revealed that in both variants 1 and 2 the plants when arranged according to vitality level from lowest to highest develop an unbroken sequence. In the selection of variant 1 seedlings, the vitality was in the amplitude from 0.39 to 0.95 (Fig. 3). On the basis of division of the seedlings by level of their vitality into five groups we determined that in this variant, in the selection, out of 30 plants 2 seedlings had c vitality (6.7\%), $13 \mathrm{~b}$ (43.3\%), 12 a (40.0\%) and 3 had the highest vitality class aa $(10.0 \%)$.

In the variant 2 selection the vitality of some plants was in the amplitude from 0.41 to 0.89 (Fig. 4). In this variant the seedlings of the lower classes of vitality $\mathrm{cc}$ and c were absent, $16(53.3 \%)$ specimens had class b, and $12(40.0 \%)$ class a and $2(6.7 \%)$ aa class. Thus, by the scale of vital condition of the plants, the seedlings of variant 2 on the graph are "shifted to the right", that is more of them had high vitality. The basis of this group of seedlings is composed of specimens of average and high vitality (Fig. 5). In general, in this variant, as the representative selection showed, specimens of low vitality were absent.

Integral evaluation of the vitality of seedlings using formula $\mathrm{Q}=$ $(a / n+a / n+b / n)$ in two variants of their planting into the open soil revealed that plants of variant 1 had $\mathrm{Q}$ coefficient equaling $\mathrm{Q}=0.93$. For variant № $2 \mathrm{Q}=1.00$. Thus, in the outdoor conditions, two-year old seedlings had better vital condition and higher morphostructural characteristics compared with the ginkgo plants of three-year seedlings. This can be explained by two circumstances. First of all, younger two-year seedlings adapted better to the environmental changes after they had been moved from greenhouse to soil compared with the seedlings transplanted at the age of three years. Secondly, in variant 2 the seedlings were in the field for three vegetative periods, whereas in variant 1 only two. Seedlings of variant 2 had more time for adaptation to the outdoor conditions.

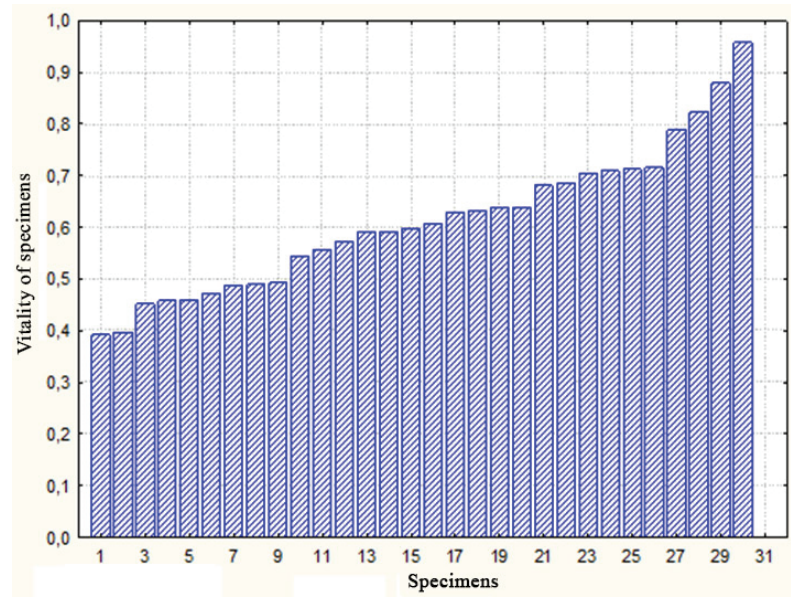

Fig. 3. Vitality of ginkgo specimens in order of its increase - variant 1

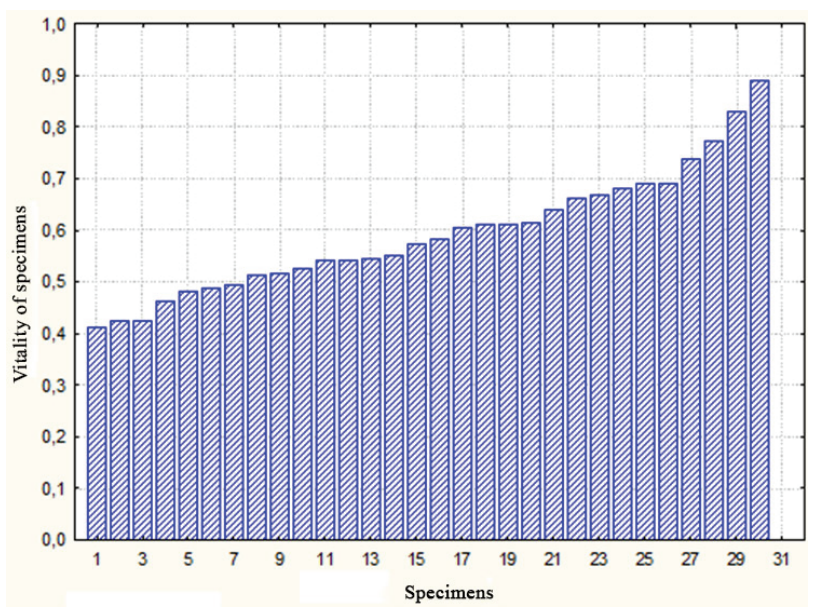

Fig. 4. Vitality of ginkgo specimens in order of its increase - variant 2
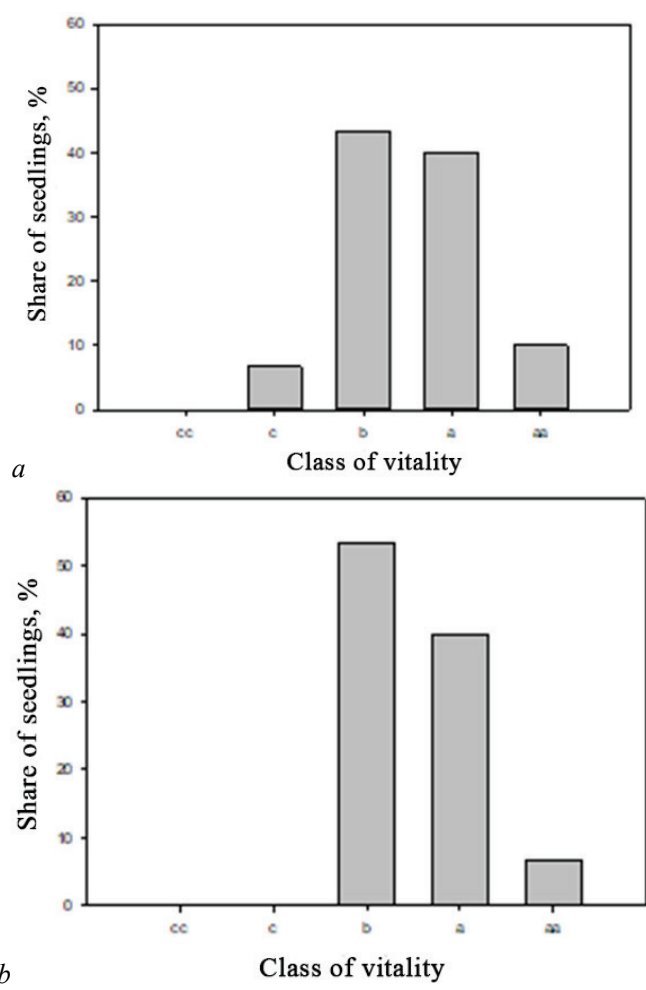

Fig. 5. Vitality structure of the ginkgo seedlings: $a$ - Variant $1, b-$ Variant 2

\section{Discussion}

Trees of G. biloba are cultivated artificially in a number of countries due to the fact that their leaves have a complex of unique medical properties (Mohanta et al., 2014; Torchik et al., 2018). Extract from the leaves is used for different diseases related to the problems of the blood vessels, hypertension (Mohanta et al., 2014; Heinonen \& Gaus, 2015; Badore et al., 2017). Moreover, the extract from ginkgo leaves contributes to improvement of memory, boosts mental and physical abilities, has anti-stress properties and strengthens immunity, etc. (Qiu et al., 2017; Zhang \& Cai, 2018). Another advantage of the medical preparations from ginkgo leaves is their complex effect on the human organism (Krauss et al., 2016; Fan et al., 2018).

For creation of industrial plantations of ginkgo, more accessible and economically effective technology is needed. One of the indicators of predicting the high vitality of plants is quality of seeds, which to a high degree is determined by their morphometric parameters. Through comparison of the obtained regression equations which allow prediction of the mass of seeds of G. biloba, one can note that all independent variables (length of seed, rim width of seed, cross-section width of seed) have statistically reliable levels of significance and cannot be excluded from the models. However, differences can be seen in the extent of their contribution. Thus, the extent of contributions of length of seed and rim width of seed to the mass of seeds collected from ginkgo plants in the conditions of forest-steppe was practically the same, and the negative value of the coefficient indicating cross-section width of seed shows that with increase in its size the seed mass decreases. And vice-versa, the amount of contributions of length and rim width of seed and crosssection width of seed to the mass of seeds collected from ginkgo plants in the conditions of steppe were not the same either by extent or by pattern (Fig. 6). At the same time, the coefficient indicating cross-section width of seed had the value which exceeded the contribution of seed length almost by three times and the value was negative. That is with increase in the length of seeds of G. biloba growing in steppe conditions (Odessa) decrease in the seed mass of this tree plant will be observed.

Therefore, the studies revealed that climatic resources of the studied region condition the statistically reliable difference in the average values of G. biloba plants' seed mass and rim width of seed. In the drier and 
hotter conditions of the South Ukraine (Odessa oblast) longer seeds will have lower mass, whereas in the more moderate and humid conditions of the forest-steppe zone such values will be in the seeds wider in crosssection.

Forest-steppe conditions
rim width of seed

Fig. 6. Prediction of the mass of seed of G. biloba growing in different climatic areas

Methods of planting ginkgo plants vary (Ivaniuk \& Zavadska, 2015). Sometimes the seedlings are grown in special containers and then transplanted into a permanent place of growth after opening the side walls of the container, ensuring the integrity of the root system. However, this is an expensive method and is used only for growing singular trees. Vegetative reproduction of ginkgo by stem cutting can also be used. The propagules produce new roots in water or in a nutrient substrate, and then are planted into soil (Glukhov et al., 2008).

The optimum age of planting seedlings of ginkgo to a permanent site is within the amplitude 4-7 years with height of $60-90 \mathrm{~cm}$. However, for better adaptation, many authors recommend planting seedlings to a permanent site at the age of no less than 10 years, because at a younger age ginkgo plants are more susceptible to winter frosts and often require additional shelter.

Our studies of plantations of $G$. biloba revealed that in both variants 1 and 2 the seedlings had high vital condition in the amplitude of $0.97-$ 1.0 according to the scale $0.0-1.0$. The difference is that transplanting seedlings outdoors at the age of three years led to the result that $6.7 \%$ of the total number had low vital condition (vitality class c), whereas after transplanting seedlings at the age of two years plants with this level of vitality were absent.

In our study, during transplantation of seedlings, maximum preservation of the root system was provided. For seedlings a pit of required size was prepared (on average equaling $0.8 \times 0.5 \times 0.5 \mathrm{~m}$ ). A drainage layer was put at the bottom. After planting, the plants were intensely watered, and then soil was covered with straw mulch. Some authors recommend adding liquid manure when planting (Gopichand \& Meena, 2015). In China, for growing ginkgo, use of fertilizers is recommended in the dose of nitrogen $-400 \mathrm{~g}$ per tree, phosphorus $-200 \mathrm{~g}$ per tree and potassium $90 \mathrm{~g}$ per tree (Jing Guo et al., 2016). This significantly increased the productivity of photosynthesis and indicates growth of stems. However, addition of fertilizers obviously should be correlated with the initial fertility of soil in the plantation.

\section{Conclusions}

Transplantation of seedlings outdoors from a greenhouse at the age of two years in the conditions of North-East Ukraine led to better growth and development of seedlings compared with seedlings which were planted into open soil at the age of three years. Comparative analysis of morphological peculiarities of ginkgo seedlings revealed that plants which were moved from the greenhouse outdoors at the age of two years had higher annual increments of the main stem, diameter of shoot and number of leaves. The vital condition of such seedlings was higher and evaluated by index $\mathrm{Q}$ in the amplitude from vitality class $\mathrm{b}$ to aa. This allowed us to recommend for North-East Ukraine a combined two-stage scheme of growing ginkgo. The optimum age for transplanting seedlings outdoors was determined as two years.

\section{References}

Badore, N. S., Das, P. K., Pillai, S., \& Thakur, A. (2017). Role of Ginkgo biloba extract, against isoproterenol induced cardiac toxicity in rats. Indian Journal of Pharmaceutical Education and Research, 51(4), 691-699.

Bikram, S., Pushpinder, K., Gopichand, R. D. S., \& Ahuja, P. S. (2008). Biology and chemistry of Ginkgo biloba. Fitoterapia, 79(6), 401-418.

Boyko, A. A., \& Brygadyrenko, V. V. (2016). Influence of water infusion of medicinal plants on larvae of Strongyloides papillosus (Nematoda, Strongyloididae). Visnyk of Dnipropetrovsk University, Biology, Ecology, 24(2), 519525.

Burda, R. I., \& Koniakin, S. N. (2019). The non-native woody species of the flora of Ukraine: Introduction, naturalization and invasion. Biosystems Diversity, 27(3), 276-290.

Crane, P. (2013). Ginkgo - the tree that time forgot. Yale University Press, Yale.

Critchfield, W. B. (1970). Shoot growth and heterophylly in Ginkgo biloba. Botanical Gazette, 131(2), 150-162.

Diamond, B. J., Shiflett, S. C., Feiwel, N., Matheis, R. J., Noskin, O, Richards, J. A., \& Schoenberger, N. E. (2000). Ginkgo biloba extract: Mechanisms and clinical indications. Archives of Physical Medicine and Rehabilitation, 81, 668-678.

Didur, O., Kulbachko, Y., Ovchynnykova, Y., Pokhylenko, A., Lykholat, T. (2019). Zoogenic mechanisms of ecological rehabilitation of urban soils of the park zone of megapolis: Earthworms and soil buffer capacity. Journal of Environmental Research, Engineering and Management, 75(1), 24-33.

Faly, L. I., Kolombar, T. M., Prokopenko, E. V., Pakhomov, O. Y., \& Brygadyrenko, V. V. (2017). Structure of litter macrofauna communities in poplar plantations in an urban ecosystem in Ukraine. Biosystems Diversity, 25(1), 29-38.

Fan, Y., Jin, X., Man, C., \& Gong, D. (2018). Does adjuvant treatment with Ginkgo biloba to statins have additional benefits in patients with dyslipidemia? Frontiers in Pharmacology, 9, 659.

Glukhov, O. Z., Dovbish, N. F., \& Kharakhota, L. V. (2008). Pryskorene vehetatyvne rozmnozhennia Ginkgo biloba L. na pivdennomu skhodi Ukrajiny [Accelerated vegetative reproduction of Ginkgo biloba $\mathrm{L}$. in the south-east of Ukraine]. Bulletin of the Nikitsky Botanical Garden, 96, 35-37 (in Ukrainian).

Gopichand, \& Meena, R. L. (2015). Standardization of propagation and agro techniques in Ginkgo biloba L. - a medicinally important plant. Journal of Medicinal Plants Studies, 3(4), 6-15.

Gorun, V. V. (2013). Ocinka rekreacijno-resursnoho potencialu terytoriji Odes'koji oblasti [Estimation of recreational resource potential of the territory of Odessa region]. Visnyk of the Lviv University, Series Geography, 43(1), 24 31 (in Ukrainian).

Guo, J., Wu, Y., Wang, B., Lu, Y., Cao, F., \& Wang, G. (2016). The effects of fertilization on the growth and physiological characteristics of Ginkgo biloba L. Forests, 7(12), 293.

Heinonen, T., \& Gaus, W. (2015). Cross matching observations on toxicological and clinical data for the assessment of tolerability and safety of Ginkgo biloba leaf extract. Toxicology, 327, 95-115.

Ivaniuk, I. V., \& Zavadska, M. O. (2014). Vyroshchuvannia sadzhantsiv hinkho dvolopatevoho v konteinernii kulturi [Cultivation of Ginkgo biloba seedlings in container culture]. Scientific Bulletin of the National University of Life and Environmental Sciences of Ukraine, Series Forestry and Ornamental Horticulture, 198(2), 87-92 (in Ukrainian).

Jacobs, B. P., \& Browner, W. S. (2000). Ginkgo biloba: A living fossil. The American Journal of Medicine, 108(4), 341-342.

Kotsariev, O. S., Antoniuk, S. V., \& Lykholat, O. A. (2001). Strukturno-funktional'ni osoblyvosti aerohematychnoho bar'iera lehen' za umov inhaliatsiinoji diji nyz'kykh kontsentratsij soli svyntsiu [Structural-functional characteristics of the air-blood barrier of lungs upon inhalation of low concentrations of lead salt]. Fiziolohichnyi Zhurnal, 47(4), 36-41.

Kovalenko, I. M., Klymenko, G. O., Yaroschuk, R. A., Fedorchuk, M. I., \& Lykholat, O. A. (2018). Optimization of Ginkgo biloba cultivation technology in open soil conditions. Regulatory Mechanisms in Biosystems, 9(4), 535-539.

Krauss, P., Tziridis, K., Buerbank, S., Schilling, A., \& Schulze, H. (2016). Therapeutic value of Ginkgo biloba extract EGb $761^{\circledR}$ in an animal model (Meriones unguiculatus) for noise trauma induced hearing loss and tinnitus. PLoS One, 11(6), $\mathrm{e} 0157574$.

Kuznetsova, S. M., \& Shulzhenko, D. V. (2015). Ekstrakt Ginkgo biloba v strategii lecheniya hronicheskih sosudistyih zabolevaniy golovnogo mozga [Ginkgo biloba extract in the treatment strategy of chronic cerebrovascular diseases]. International Neurological Journal, 2, 109-115 (in Russian).

Kyrylchuk, K. S. (2014). Populiatsiina struktura Medicago falcata L. na zaplavnykh lukakh lisostepovoi zony $\mathrm{v}$ umovakh pasovyshchnykh ta sinokisnykh navantazhen [Population structure of Medicago falcata $\mathrm{L}$. in floodplain meadows of the forest-steppe zone under pasture and hay conditions]. Visnyk Kharkivskoho Natsionalnoho Universytetu Imeni V. N. Karazina, Biolohiia, $1100,305-314$ (in Ukrainian). 
Leigh, A., Zwieniecki, M. A., Rockwell, F. E., Nicotra, A. B., \& Holbrook, N. M. (2011). Structural and hydraulic correlates of heterophylly in Ginkgo biloba. New Phytologist, 189, 459-470.

Lobstein, A., Rietsch-Jako, L., Haag-Berrurier, M., \& Anton, R. (1991). Seasonal variations of the flavonoid content from Ginkgo biloba leaves. Planta Medica, 57(5), 430-433.

Lykholat, T., Lykholat, O., \& Antonyuk, S. (2016). Immunohistochemical and biochemical analysis of mammary gland tumours of different age patients. Cytology and Genetics, 50(1), 40-51.

Lykholat, Y. V., Khromykh, N. O., Pirko, Y. V., Alexeyeva, A. A., Pastukhova, N. L., \& Blume, Y. B. (2018b). Epicuticular wax composition of leaves of Tilia $\mathrm{L}$. trees as a marker of adaptation to the climatic conditions of the steppe Dnieper. Cytology and Genetics, 52(5), 323-330.

Lykholat, Y., Khromykh, N., Didur, O., Alexeyeva, A., Lykholat, T., \& Davydov, V. (2018a). Modeling the invasiveness of Ulmus pumila in urban ecosystems under climate change. Regulatory Mechanisms in Biosystems, 9(2), 161-166.

Mahadevan, S., \& Park, Y. (2008). Multifaceted therapeutic benefits of Ginkgo biloba L.: Chemistry, efficacy, safety, and uses. Journal of Food Science, 73(1), 14-18.

Mohanta, T. K., Tamboli, Y., \& Zubaidha, P. K. (2014). Phytochemical and medicina importance of Ginkgo biloba L. Natural Product Research, 28(10), 746-752.

Nazarenko, M., Lykholat, Y., Grigoryuk, I., \& Khromykh, N. (2018). Optimal doses and concentrations of mutagens for winter wheat breeding purposes. Part I. Grain productivity. Journal of Central European Agriculture, 19(1), 194-205.

Ostudimov, A. O. (2011). Hinkho dvolopateve v Ukraini: Nasinnyi potentsial, osoblyvosti vyroshchuvannia ta vykorystannia sadyvnoho materialu [Ginkgo biloba in Ukraine: Seed potential, features of growing and use of planting material]. Lviv (in Ukrainian).

Ostudimov, A. O., \& Guz, M. M. (2010). Osoblyvosti nasinnoho rozmnozhennia hynkho dvolopatevoho [Features of seed reproduction of Ginkgo biloba]. Scientific Bulletin of Ukrainian National Forestry University, 20(11), 8-16 (in Ukrainian)

Pertseva, T. A., Lykholat, E. A., \& Gurzhiy, E. V. (2008). Vliyanie tiotropiya bromida na sostoyanie mukociliarnogo klirensa u bol'nyh hronicheskim obstruktivnym zabolevaniem legkih [The influence of tiotropium bromide on mucociliary clearance's condition in patients with chronic obstructive pulmonary disease]. Ukrainian Pulmonology Journal, 1, 13-15 (in Ukrainian).

Pertseva, T., Lykholat, O., \& Gurzhiy, O. (2012). Influence of tiotropium bromide (TB) and carbocysteine (C) on mucociliary clearance (MCC) in patients with COPD. European Respiratory Journal, 40(56), 3466.

Po-Chuen, C., Qingsu, X., \& Peter, P. F. (2007). Ginkgo biloba leave extract: Biological, medicinal, and toxicological effects. Journal of Environmental Science and Health, 25, 211-244

Pokhylenko, A., Lykholat, O., Didur, O., Kulbachko, Y., \& Lykholat, T. (2019) Morphological variability of Rossiulus kessleri (Diplopoda, Julida) from different biotopes within Steppe Zone of Ukraine. Ukrainian Journal of Ecology, 9(1), 176-182.

Qiu, J., Chen, X., Netrusov, A. I., Zhou, Q., Guo, D., Liu, X., He, H., Xin, H., Wang, Y., \& Chen, L. (2017). Screening and identifying antioxidative components in Ginkgo biloba pollen by DPPH-HPLC-PAD coupled with HPLC-ESI-MS2. PLoS One, 12(1), e0170141.

Rimkiene, L., Kubiliene, Zevzikovas, F., Kazlauskiene, D., \& Jakstas, V. (2017). Variation in flavonoid composition and radical-scavenging activity in Ginkgo biloba L. due to the growth location and time of harvest. Journal of Food Quality, 2017, 6840397.

Samorodov, V. N., \& Pospelova, A. D. (2016). Bolezny hynkho dvulopastnoho: Poltavskyi aspekt [Diseases of Ginkgo biloba: Poltava aspect]. Medicinal plant-growing: From experience of the past to the latest technologies. Proceedings of the Fifth International Scientific and Practical Internet Conference. Pp. 145-146 (in Russian).

Savosko, V., Lykholat, Y., Domshyna, K., \& Lykholat, T. (2018). Ekolohichna ta heolohichna zumovlenist poshyrennia derev i chaharnykiv na devastovanykh zemliakh Kryvorizhzhia [Ecological and geological determination of trees and shrubs' dispersal on the devastated lands at Kryvorizhya]. Journal of Geology, Geography and Geoecology, 27(1), 116-130 (in Ukrainian).

Schmid, W., \& Balz, J. P. (2003). Cultivation of Ginkgo biloba L. on three continents. III WOCMAP Congress on Medicinal and Aromatic Plants, 2, 177-180.

Shchyrova, Y. V., Serbin, A. H., \& Kartmazova, L. S. (2002). Morfoloho-anatomichne doslidzhennia lystkiv hinkho dvolopatevoho [Morphological-anatomical study of Ginkgo biloba leaves]. News of Pharmacy, 32, 19-22 (in Ukrainian).

Singh, B., Kaur, P., Gopichand, Singh, R. D., \& Ahuja, P. S. (2008). Biology and chemistry of Ginkgo biloba. Fitoterapia, 79(6), 401-418.

Skliar, V. H. (2013). Pryrodne ponovlennia duba zvychainoho na terytorii NovhorodSiverskoho Polissia: Poshyrenist u fitotsenozakh ta dyferentsiatsiia yikh umov za stupenem spryiatlyvosti dlia tsoho protsesu [Natural renewal of common oak in the territory of the Novgorod-Siversky Polissya: Prevalence in phytocenoses and differentiation of their conditions by the degree of favorableness for this process]. Pytannia Bioindykatsii ta Ekolohii, 18(2), 56-70 (in Ukrainian).

Skliar, V. H., \& Zlobin, Y. A. (2013). Vnutrishnopopuliatsiina struktura ta metodyka yii vyvchennia u derevnykh lisoutvoriuiuchykh vydiv [Intra-population structure and methods of its study in tree forest-forming species]. Chornomorski Botanical Journal, 9(3), 316-329 (in Ukrainian).

Tereshchuk, A. I. (2009). Hynkho - tsilytel [Ginkgo is a healer]. Lohos Ukraina, Kyiv (in Ukrainian).

Tikhonova, E. M. (2011). Vitalitetna struktura populiatsii deiakykh vydiv burianiv u posivakh zernovykh kultur [Vitality structure of the populations of some weed species in crop sowings]. Visnyk of Dnipropetrovsk University, Biology, ecology, 19(1), 123-129 (in Ukrainian).

Torchik, V. I., Holopuk, G. A., \& Kel'ko, A. F. (2018). Perspektivy introdukcii ginkgo dvulopastnogo (Ginkgo biloba L.) v Belarusi [Prospects for the introduction of Ginkgo biloba L. in Belarus]. Izvestija Nacional'noj Akademii Nauk Belarusi, Serija Biologicheskih Nauk, 63(1), 27-32 (in Russian).

Trygub, V. I., Bochevar, S. V., \& Kupchik, A. M. (2016). Gruntovo-ekologichni osoblyvosti mis'kyh gruntiv (na prykladi m. Odesy) [Soil-ecological peculiarities of urban soil (by the example of city of Odessa)]. Visnyk Odes'kogo Natsionalnogo Universytetu, Seriya Geografichni i Geologichni Nauky, 21(1), 98 109 (in Ukrainian).

Vasilenko, I. D. (1972). Diagnostirovanie pola u seyantsev topoley s pomoschyu biohimicheskih reaktsiy [Diagnosis of sex in poplar seedlings using biochemical reactions]. Lesnoy Zhurnal, 1, 141-142 (in Russian).

Yaroshchuk, R. A. (2016). Perspektyvy vyroshchuvannia Ginkgo biliba L. v umovakh pivnichno-skhidnoho lisostepu Ukrajiny dlia zahotivli lystia u farmatsevtychnykh tsiliakh [Prospects of cultivation of Ginkgo biliba L. in the conditions of the North-Eastern Forest-Steppe of Ukraine for harvesting leaves for pharmaceutical purposes]. Ahronomiia i Biolohiia, 32, 124-128 (in Ukrainian).

Yoshikawa, T., Naito, Y., \& Kondo, M. (1999). Ginkgo biloba leaf extract: Review of biological actions and clinical applications. Antioxidants and Redox Signaling, 1(4), 469-480

Yudina, Y. V., Kryklyvaia, I. O., Ruban, O. A., Demianenko, V. H., \& Maslii, Y. S. (2010). Doslidzhennia yakisnoho ta kilkisnoho vmistu polifenolnykh spoluk u lystkakh Ginkgo biloba [nvestigation of qualitative and quantitative content of polyphenolic compounds in Ginkgo biloba leaves]. Ukrainian Journal of Clinical and Laboratory Medicine, 5(2), 49-52 (in Ukrainian).

Zhang, X., \& Cai, Y. (2018). Effects of Ginkgo biloba leaf extract, shenmai and matrine on a human embryonic lung fibroblast fibrosis model. Experimental and Therapeutic Medscine, 16(5), 4289-4295.

Zlobin, Y. A. (2018). Alhorytm otsinky vitalitetu osobyn roslyn i vitalitetnoi struktury fitopopuliatsii [An algorithm for estimating the vitality of plant individuals and the vital structure of phytopopulations]. Chornomorski Botanical Journal, 14(3), 213-226 (in Ukrainian).

Zlobin, Y. A., \& Klimenko, G. O. (2010). Shcho my znaiemo i shcho ne znaiemo pro ridkisni roslyny [What we know and what we do not know about rare plants]. Chornomorski Botanical Journal, 6(2), 150-161 (in Ukrainian). 